\title{
Coulisses
}

Revue de théâtre

13 | Hiver 1996

Varia

\section{L'Epidémie des démagogues?}

\section{Olga Escribano}

\section{OpenEdition}

Journals

Édition électronique

URL : http://journals.openedition.org/coulisses/4185

DOI : $10.4000 /$ coulisses.4185

ISSN : 2546-9460

\section{Éditeur}

Presses universitaires de Franche-Comté

\section{Édition imprimée}

Date de publication : 1 janvier 1996

Pagination : 57

ISSN : 1150-594X

\section{Référence électronique}

Olga Escribano, «L'Epidémie des démagogues? », Coulisses [En ligne], 13 | Hiver 1996, mis en ligne le 15 mars 2019, consulté le 04 octobre 2020. URL : http://journals.openedition.org/coulisses/4185 ; DOI : https://doi.org/10.4000/coulisses.4185

Ce document a été généré automatiquement le 4 octobre 2020.

Coulisses 


\title{
L’Epidémie des démagogues?
}

\author{
Olga Escribano
}

Démagogue : politicien qui flatte les masses pour gagner et exploiter leur faveur.

2 La critique de la société bourgeoise de la fin du XIXème siècle qui était égoöste, démagogue et qui pouvait changer son discours idéologique et politique en fonction des circonstances et toujours avec l'unique but de son profit personnel, est le sujet principal dans l'œuvre L'Épidémie représentée par le théâtre universitaire du 23 au 25 novembre à la faculté des lettres de Besançon...

Une question s'impose: existe-t-il encore une classe sociale avec les mêmes caractéristiques ?...

3 On trouve en Espagne une classe sociale dans le même état de développement (ou sousdéveloppement) démagogique que ce que représente L'Épidémie. Je me réfère aux présidents des équipes de football. Impulsifs, passionnés et égoïstes avec leurs gros ventres, ils apparaissent chaque semaine à la télévision pour faire des déclarations sur les derniers événements du football, déclarations qui sont souvent en contradiction avec celles qu'ils ont faites la semaine précédente. En Espagne le football n'est pas seulement un sport, il est le véhicule de la politique, de l'idéologie, du nationalisme... ou des intérêts économiques.

4 Le jour du 25 Novembre, pendant que les personnages de la pièce chantaient $L a$ Marseillaise, j'ai eu l'impression d'être une journaliste dans une conférence de presse de Josep Lluis Nunez, président $d u$ «Barça " (l'équipe de football de Barcelone) qui chantait avec les dirigeants de cette équipe la chanson du «Barça » après avoir gagné un match national. 


\section{AUTEURS}

OLGA ESCRIBANO

Étudiante Erasmus, Université de Barcelone 